\title{
Evaluation of hip angles with magnetic resonance imaging in femoroacetabular impingement syndrome
}

\author{
Femoroasetabular impingement sendromunda manyetik rezonans \\ görüntüleme ile kalça açılarının değerlendirilmesi
}

\section{Turgut Kültür ${ }^{1}$, (D) Mikail İnal ${ }^{2}$}

${ }^{1}$ Department of Physical Medicine and Rehabilitation, School of Medicine, Kırıkkale University, Kırıkkale, Turkey ${ }^{2}$ Department of Radiology, School of Medicine, Kırıkkale University, Kırıkkale, Turkey

Cite this article as / Bu makaleye atıf için: Kültür T, İnal M. Evaluation of hip angles with MRI in femoroacetabular impingement syndrome. J Health Sci Med 2020; 3(3): 225-230.

\begin{abstract}
Introduction: It was aimed to compare the patients having clinical and radiological diagnosis of femoroacetabular impingement syndrome with the control group by magnetic resonance imaging, and alpha angle and the central corner angle described by Wiberg.

Material and Method: Routine hip MRIs were analyzed retrospectively between January 2016 and May 2019. Clinically and radiologically, patients diagnosed with cam, pincer, and mixed FAI were recorded. A control group matching age and sex was created. The alpha angle was determined as the angle between the line drawn from the center of the femoral neck to the center of the femoral head in axial T1A magnetic resonance imaging, and the line drawn from the center of the femoral head to the point where the femoral head begins to turn towards the neck.Central corner angle of Wiberg's was measured as the angle between the perpendicular line drawn from the center of the femoral head to the acetabulum on the coronal T1A images and the line connecting the outermost point of the acetabulum. Measurements were compared statistically in both groups. $\mathrm{p}<0.05$ was considered statistically significant.

Results: 16 of 28 patients ( 18 men, 10 women) with FAI had impingement in both hips and a total of 44 hips were examined. There were 9 cam, 23 pincer and 12 mixed impingement cases in the patient group. When FAI and control groups were compared, alpha and Wiberg's angles were found to be significantly different $(\mathrm{p}<0.05)$. In subgroup analysis, there was a significant difference between cam type and control group, mixed type and control group, pincer type and cam type, pincer type and mixed type in terms of alpha angles $(\mathrm{p}<0.05)$. For Wiberg's angles, a significant difference was found between pincer type and control group, mixed type and control group, pincer type and cam type, mixed type and cam type $(p<0.05)$. Cut off values were 54.45 (auc $=0.64)$ for alpha angle and 37.30 (auc=0.83) for Wiberg angle.
\end{abstract}

Conclusion: Alpha angle measurement cam type and Wiberg angle measurement provide useful information for the diagnosis of pincer type impingement with MRI.

Keywords: Hip, femur, acetabulum, impingement, alpha angle, Wiberg angle

\section{ÖZ}

Giriş: Klinik ve radyolojik Femoroasetabular sıkışma sendromu (FAI) tanılı hastaların manyetik rezonans görüntülemelerdeki (MRG) alfa ve Wiberg tarafından tanımlanan merkezi köşe açı değerlerinin kontrol grubu ile karşılaştırılması amaçlandı.

Gereç ve Yöntem: Ocak 2016 ile Mayıs 2019 arası rutin kalça manyetik rezonans görüntüleri retrospektif olarak incelendi. Klinik ve radyolojik olarak cam, pincer ve mikst tip femoroasetabular sıkışma tanısı alan hastalar kaydedildi. Yaş ve cinsiyet eşleştilmiş bir kontrol grubu oluşturuldu. Alfa açısı, aksiyal T1A manyetik rezonans görüntülemelerde femur boyun merkezinden femur başı merkezine çizilen çizgi ile, femur başı merkezinden anteriyor tarafta femur başının boyna doğru dönmeye başladığı noktaya çizilen çizgi arasındaki açı olarak belirlendi. Wiberg'in merkezi köşe açısı, koronal T1A görüntülerde femur başının merkezinden asetabuluma çekilen dikey çizgi ile asetabulumun en dıştaki noktasını birleştiren çizgi arasındaki açı olarak ölçüldü. Ölçümler her iki grupta istatistiksel olarak karşılaştırıldı. $\mathrm{p}<0,05$ istatistiksel olarak anlamlı kabul edildi.

Bulgular: Femoroasetabular sıkışma sendromlu 28 hastanın 16’sında (18 erkek, 10 kadın) her iki kalçada sıkışma vardı ve toplam 44 kalça incelendi. Hasta grubunda 9 cam, 23 pincer ve 12 mikst tip sıkışma vakası vardı. Femoroasetabular sıkışma ve kontrol grupları karşılaştırıldığında alfa ve Wiberg açıları anlamlı olarak farklı bulundu $(\mathrm{p}<0,05)$. Alt grup analizinde alfa açıları açısından cam tipi ile kontrol grubu, mikst tipi ile kontrol grubu, pincer tipi ile cam tipi, pincer tipi ile mikst tipi arasında anlamlı fark vardı $(\mathrm{p}<0,05)$. Wiberg açları için pincer tipi ve kontrol grubu, mikst tipi ve kontrol grubu, pincer tipi ve cam tipi, mikst tipi ve cam tipi arasında anlamlı bir fark vardı $(\mathrm{p}<0,05)$. Cut-off değerleri alfa açısı için 54,45 (auc=0,64) ve Wiberg açısı için 37,30 (auc=0,83) idi. Sonuç: Alfa açısı ölçümü cam tipi ve Wiberg açısı ölçümü manyetik rezonans görüntüleme ile pincer tipi sıkışma tanısı için yararlı bilgiler sağlar. Anahtar Kelimeler: Kalça, femur, astebulum, impingement, alfa açısı, Wiberg açısı 


\section{INTRODUCTION}

Femoroacetabular impingement syndrome (FAI) usually originates from the anterior part of the coxafemoral joint and is the main cause of hip osteoarthritis (OA) in young people. FAI is classified into two subtypes, including pincer and cam and the limitation in the range of joint motion leads to cartilage damage and labral tear due to the impact of the femoral head-neck junction to the acetabulum, especially in flexion or internal rotation performed during flexion. In the pincer type, which is acetabular component of FAI, the femoral head and neck are normal and develops due to the contiguity between the acetabular edge and the femoral head $(1,2)$. In this type of impingement, which is frequently seen in middle-aged women, there is a focal or general overcoating of the femoral head by the acetabulum due to the increase in the depth of the acetabulum. In some cases, this may be due to reasons such as coxa profunda, protrusioacetabuli, retroversion of the acetabulum, etc. As a result, the acetabular labral tear develops in the beginning. In hip flexion, a secondary injury may occur due to mild subluxation in the posterior lower part of the joint that corresponds to the opposite side of the bone area exposed to trauma. Labral and chondral degeneration may eventually cause early hip OA (1-6). The type of cam of FAI, which is the femoral component, is often observed in young athletic men. The femoral head, which is forced to enter the acetabular ring, due to the decrease in the neck angle, during hip flexion and internal rotation, rests on the acetabular edge. Repetitive compression leads to new bone formation in the anterior and superior of the femoral neck. This condition further enhances compression, by reducing the head-neck angle. Most patients have a combination of both types, which is called "mixed". A lesser group of patients have only one of pincer or cam type. In the diagnosis plain radiographs are often used. The alpha angle gives accurate results in the diagnosis of FAI and it is easy to measure. The alpha angle, whose normal value is $20-40^{\circ}$, is higher in camtype impingement and the rate of cartilage and labrum damage increases as the value increases. Alpha angle does not correlate with age. The measurement of alpha angle defined on MRI was also found to be reliable on plain radiographs (1-10). The Center Edge (CE) angle is defined by Wiberg and gives information about the lateral covering of the femoral head by the acetabulum on the coronal plane. A greater value of angle shows a deep acetabulum, whereas a smaller value of angle indicates both an overflowing femoral head and a shallow acetabulum. The CE angle defined by Wiberg measures the femoral head-acetabulum relationship in the frontal plane. It includes the measurement of the angle between the line connecting the side edge of the acetabulum center of the femoral head and the line drawn perpendicular to the center of the femoral head. The concentric circle method is used to determine the center of the femoral head. In this method, it is recommended that the outer circle fits into the upper side and the bottom of the femoral head $(1,2)$. To the best of our knowledge, in the literature, there is no study investigating pincer type FAI by using Wiberg angle on MRI images.

There may be differences in the treatment of either types of FAI. In addition, delay in diagnosis may cause conservative treatment inefficient and require surgery. Therefore, early diagnosis and detection of the type is of upmost importance.

The aim of this study was to evaluate the alpha angle and the central corner angle described by Wiberg, in patients clinically and radiologically diagnosed with Femoroacetabular impingement (FAI) by using MRI and compare them with healthy controls. Thus determining the diagnostic value of these angles in FAI types.

\section{MATERIAL AND METHOD}

In this retrospective study, MR images of patients clinically and radiologically diagnosed with cam, pincer, and mixed types of FAI, between January 2015 and August 2019, in the radiology clinic of Krrikkale University Faculty of Medicine, obtained by using 1.5-Tesla MR scanner Philips MRI Systems, Achieva Release 3.2 Level 2013-10-21, Philips Medical Systems Nederland BV devices were evaluated. This study was approved by the university /local human research ethics committee and all procedures performed in studies involving human participants were in accordance with the ethical standards of the institutional and/or national research committee and with the 1964 Helsinki Declaration and its later amendments or comparable ethical standards. The study was carried out with the permission of Kirıkkale University Non-Interventional Research Ethics Committee. (Permission granted /Date: 09/10/2019, Number of meetings: 2019/16, Decision no: 2019.10.08).

Patients who had a history of osteoarthritis, trauma, and surgery were excluded from the study. A control group matching the study group in terms of age and gender was formed. The alpha angle and the center corner angle described by Wiberg were compared between the FAI patients and the healthy controls. The alpha angle was measured on the axial T1A MRI images by calculating the angle between the parallel line drawn from the center of the femoral head to the femoral neck and the line drawn from the transition point between the femoral head and femoral neck in the anterior to the center of the femoral head (Figure 1). Central corner angle of Wiberg was measured on the coronal T1A images by calculating 
the angle between the perpendicular line drawn from the center of the femoral head to the acetabulum and the line connecting the outermost point of the acetabulum (Figure 2). Measurements were compared statistically between the groups. A value of $\mathrm{p}<0.05$ was considered statistically significant.

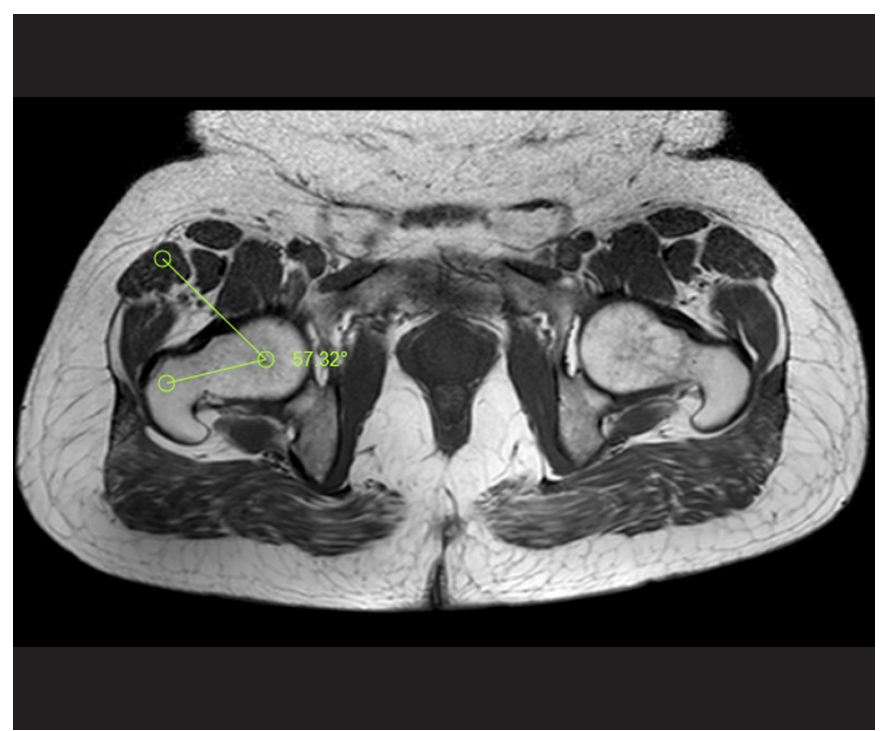

Figure 1. 43-year-old male, alpha angle measurement.

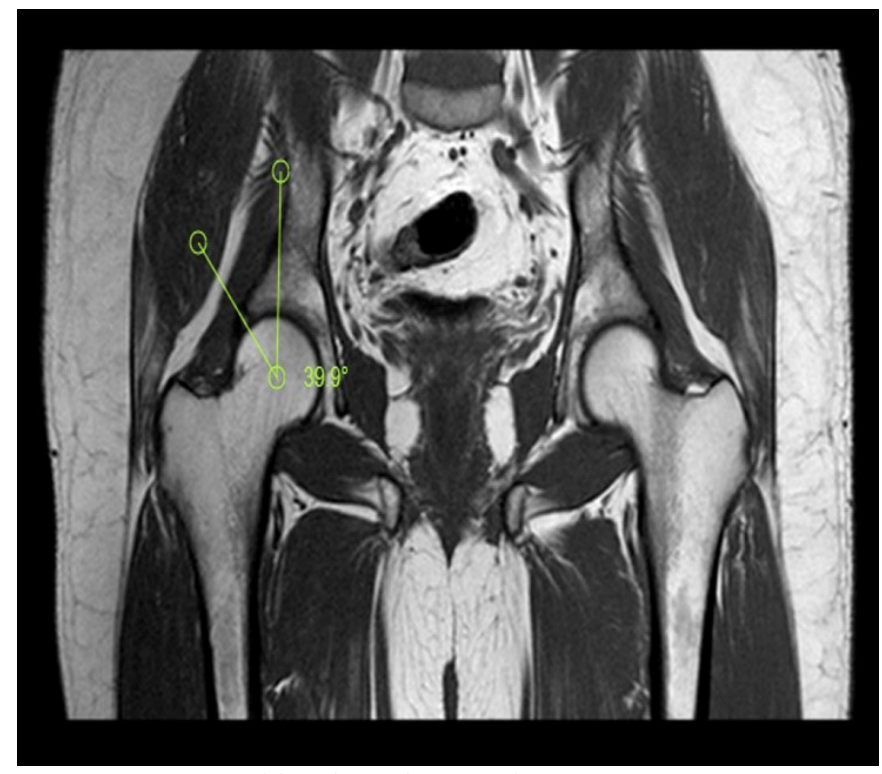

Figure 2. 36-year-old male, Wiberg angle measurement

\section{Statistical Analyses}

All statistical analyses were performed by using SPSS 16.0 (SPSS, Chicago, IL) Statistical package program. Nonparametric tests were used in the analyses since

Kolmogorov-Smirnov and Shapiro-Wilk tests showed that the groups did not distributed normally. In comparisons of patient and control groups, age was evaluated by using Man Whitney $\mathrm{U}$ test and gender was evaluated by using Fisher exact test. Comparisons of continuous variables such as angular values with more than two groups were performed by using the Kruskal Wallis test. Man Whitney $\mathrm{U}$ test with Bonferroni correction was performed for double comparison of these groups. Categorical variables are presented as numbers and percentages. Continuous variables are presented as median and minimummaximum. Cuttoff values of alpha and Wiberg angles were determined by using Roc Curve Analyse (ROC) test. A value of $\mathrm{p}<0.05$ at $95 \%$ confidence interval were accepted to be statistically significant.

\section{RESULTS}

There was no difference between the groups in terms of age and gender $(\mathrm{p}>0.05)$. The FAI group consisted of 28 patients, including 18 males and 10 females. In the FAI group, 16 (57.1\%) patients had impingement in both hips and a total of 44 hips ( 30 men, 14 women) were examined. The control group consisted of 30 men and 12 women. The study group was divided in to three subgroups according to impingement types; There were 9 cam types, 23 pincers and 12 mixed types. We found statistically significant differences between the study and control groups in terms of alpha and Wiberg angles $(\mathrm{p}=0.03$ and $\mathrm{p}=0.01$, respectively) (Table $\mathbf{1})$.

\begin{tabular}{|c|c|c|c|}
\hline & FAI & Control group & p-value \\
\hline $\begin{array}{l}\text { Age Median } \\
(\min -\max )\end{array}$ & $\begin{array}{c}49.50 \\
(18-72) \\
\end{array}$ & $\begin{array}{c}48 \\
(21-70) \\
\end{array}$ & $0.72^{\mathrm{a}}$ \\
\hline \multicolumn{4}{|l|}{ Gender n-\% } \\
\hline Male & $30-68.18 \%$ & $30-71.42 \%$ & \multirow{2}{*}{$0.82^{\mathrm{b}}$} \\
\hline Female & $14-31.82 \%$ & $12-28.87 \%$ & \\
\hline $\begin{array}{l}\text { Alpha Angle } \\
\text { Median (min-Max) }\end{array}$ & $\begin{array}{c}57.75 \\
(38.40-77.70)\end{array}$ & $\begin{array}{c}49.95 \\
(38.30-72.00)\end{array}$ & $0.03^{c}$ \\
\hline $\begin{array}{l}\text { Wiberg Angle } \\
\text { Median (min-Max) }\end{array}$ & $\begin{array}{c}41.10 \\
(30-57)\end{array}$ & $\begin{array}{c}35.30 \\
(28.70-45) \\
\end{array}$ & $0.01^{\mathrm{c}}$ \\
\hline \multicolumn{4}{|c|}{$\begin{array}{l}\text { FAI-Femoroacetabular impingement, } \\
\text { a: Man Whitney U test } \\
\text { b: Fisher Exact test } \\
\text { c: Kruskal-Wallis Test }\end{array}$} \\
\hline
\end{tabular}

In subgroup analysis, there was a significant difference between cam type and control group, mixed type and control group, pincer type and cam type, pincer type and mixed type in terms of alpha angles $(\mathrm{p}=0.01, \mathrm{p}=0.02$, $\mathrm{p}=0.01$, and $\mathrm{p}=0.02$, respectively). There was no difference between the pincer subgroup and control group and cam subgroup and mixed subgroup ( $\mathrm{p}=0.99$ and $\mathrm{p}=0.99$ ).

For Wiberg's angles, a significant difference was found between pincer type and control group, mixed type and control group, pincer type and cam type, mixed type and cam type $(\mathrm{p}=0.01, \mathrm{p}=0.01, \mathrm{p}=0.03, \mathrm{p}=0.03$, respectively $)$. There was no difference between cam subgroup and control group and between pincer subgroup and mixed subgroup ( $\mathrm{p}=0.99$ and $\mathrm{p}=0.99$ ) (Table 2.). 


\begin{tabular}{|c|c|c|c|c|c|}
\hline & Cam type & Pincer type & Mixt type & Control group & $p$ value \\
\hline $\begin{array}{l}\text { Alfa angle Median } \\
\text { (min-Max) }\end{array}$ & $69.90(45.60-77.70)$ & $45.60(38.40-70.10)$ & $67.60(47.50-72.30)$ & $49.95(38.30-72.00)$ & $\begin{array}{l}0.01^{\star} \\
0.99^{* *} \\
0.02^{* * *} \\
0.01^{\star * * *} \\
0.99^{* * * * *} \\
0.02^{* * * * * *}\end{array}$ \\
\hline \multicolumn{6}{|c|}{$\begin{array}{l}\text { FAI-Femoroacetabular impingement, } \\
\text { a: Mann Whitney U testi (With Bonforoni correction) } \\
\mathrm{p}^{*} \text { Cam type-control group comparison, } \\
\mathrm{p}^{* *} \text { Pincer type-control group comparison, } \\
\mathrm{p}^{* * *} \text { Mix type-control group comparison, } \\
\mathrm{p}^{* * * *} \text { Pincer-cam } \\
\mathrm{p}^{* * * * *} \text { Mixt-cam } \\
\mathrm{p}^{* * * * * *} \text { Pincer-mixt type comprasion }\end{array}$} \\
\hline
\end{tabular}

In ROC analysis, cut off values were found to be 54.45 (auc=0.64) for alpha angle and 37.30 (auc=0.83) for Wiberg angle.

\section{DISCUSSION}

FAI affects $7 \%$ to $23 \%$ of the population and the clinical diagnosis is becoming increasingly important (11). FAI is a condition that is predisposed to the development of early osteoarthritis due to its morphological and mechanical effects on the hip joint. The cam-type (femoral component of FAI) is a condition that occurs with loss in the globalization of the femoral head-neck junction and a decrease in the head-neck plane. Pincer type (an acetabular component of FAI) refers to greater global or focal over-coverage of the acetabulum femoral head (1-4).

In our study, we found that the alpha angle detected in MRI was significantly higher in cam-type and the Wiberg angle was higher in Pincer type impingement. In addition, the angles were higher in the Mixed type, which is a combination of pincer and cam-type, in comparison to the healthy controls. This finding is relevant with the findings obtained by plain radiography and CT. There were no significant differences between the mixed type and the cam type, in terms of the alpha angle values and between the mixed type and the pincer type in terms of Wiberg angle values. The fact that the mixed type has similar properties with both cam and pincer impingements makes this finding understandable.

In a study conducted on 641 patients who underwent surgical treatment for FAI, the bilateral symptomatic FAI rate was reported to be $21 \%$ (11). Allen et al. reported asymptomatic bilateral involvement in cam-type as $77.8 \%$ (12). In our study, this rate was found to be $57.1 \%$. This is a value between these two studies. We do not know to what extent the bilateral involvements in our study are symptomatic or asymptomatic.
The alpha angle is easy to measure and gives accurate results in FAI. The normal value of the alpha angle is 20$40^{\circ}$ and is determined higher in cam-type impingement and as the value increases, the rate of cartilage and labrum damage increases. Alpha angle does not correlate with age. The measurement of alpha angle defined on MRI was also found to be reliable on plain radiographs.

Since a normal, spherical shaped femoral head can be seen on flat radiographs, in some FAI cases, crosssectional, multi-plane images are required to exclude the presence of Cam deformity $(5-7,13)$. Allen et al. found cut off value for alpha angle in the hips with painful cam -impingement as 55.50 (12). Hatakeyama et al. accepted an alpha angle of 55 and above to indicate cam-type (14). In our study, the cut-off value for alpha angle was 54.450 in patients with FAI. This finding is important to show a similarity between the alpha angles, thus the relationship between femoral head and neck, in camtype impingement, in different populations.

Since our MRI findings are compatible with the measurements found on plain radiographs, it may be suggested that it is not required for clinicians to order MRI in most cases of cam type. The Center Edge angle was defined by Wiberg and gives information about the lateral covering of the femoral head by the acetabulum in the coronal plane. Larger angles indicate a deep acetabulum whereas smaller angles values indicate both overflowing of the femoral head and shallowness of the acetabulum. Wiberg angle is defined by measuring the angle between the line connecting the lateral edge acetabulum with the center of the femoral head and the line drawn perpendicular to the center of the femoral head. The concentric circle method is used to determine the center of the femoral head. In this method, it is recommended that the outer circle fits into the upper side and the bottom of the femoral head $(1,2)$. 
Although protrusio acetabuli, which is one of the etiological causes of Pincer type, has been studied with MRI, (15), to the best of our knowledge, there is no study examining Wiberg angle on MRI in Pincer type. Montazam et al. determined that the measurement of Wiberg angle by CT was compatible with Radiography in FAI (16). On the contrary, there are studies suggesting that the Wiberg angle measurement by CT is incompatible with the measurement by radiography in patients with pincer type (17). In our study, the cutoff value for Wiberg angle was found to be 37.30 (18). In this regard, it can be thought that the Wiberg angle may differ according to the radiological technique used. One reason for the smaller cut of value of the Wiberg angle is that MRI offers a more cross-sectional and more precise evaluation.

The Wiberg angle is the primary the radiographic measurement in the evaluation of acetabular dysplasia and the pincer type of FAI. Our study is important in terms of being the first study to use the Wiberg angle on MR in the determination of FAI.

In this regard, $M R$ is superior to the radiographic measurement. The advantages of MRI includes its being ionizing radiation-free and its ability to show labral and chondral damages in FAI, whereas its higher cost is its disadvantage $(1,2)$.

Limitations of our study include the low number of cases and being a retrospective study. If our number of cases would be higher, the cut-off values we found would be more reliable. The diagnosis of FAI is based on the association of a number of clinical data, including hip pain, limitation of motion, the positivity of the clinical impingement test, and imaging findings. The retrospective study design also did not allow us to perform motion testing or impingement provocation maneuvers on the hip joints. In addition, the lack of evaluation of occupations and activity levels can be regarded as limitations of this study. In addition, if the interobserver evaluation was made in this study, the evaluation of the data would be more reliable.

As a result, delay in diagnosis in FAI may cause the conservative treatment to be ineffective and make surgery necessary. In this regard, early diagnosis and detection of the type is very important. MRI is an important imaging method that has the potential to detect degenerative changes in the hip joint at an earlier stage than the other traditional imaging methods. We found that measurement of Alpha angle by using MRI provides useful information in the diagnosis of cam type and measurement of Wiberg angle in the diagnosis of pincer type impingement.

\section{ETHICAL DECLARATIONS}

Ethics Committee Approval: The study was carried out with the permission of Kirıkale University NonInterventional Research Ethics Committee. (Permission granted/ Date 09/10/2019, Number of meetings: 2019/16, Decision no: 2019.10.08).

Informed Consent: Because the study was designed retrospectively, no written informed consent form was obtained from patients.

Referee Evaluation Process: Externally peer-reviewed.

Conflict of Interest Statement: The authors have no conflicts of interest to declare.

Financial Disclosure: The authors declared that this study has received no financial support.

Author Contributions: All of the authors declare that they have all participated in the design, execution, and analysis of the paper, and that they have approved the final version.

\section{REFERENCES}

1. Keogh MJ, Batt ME. A review of femoroacetabular impingement in athletes. Sports Med 2008; 38: 863-78.

2. Matcuk Jr GR, Price SE, Patel DB, White EA, Cen S. Acetabular labral tear description and measures of pincer and cam-type femoroacetabular impingement and interobserver variability on 3 T MR arthrograms. Clinical Imaging 2018; 50: 194-200.

3. Griffin DR, Dickenson EJ, O'donnell J, et al. The Warwick Agreement on femoroacetabular impingement syndrome (FAI syndrome): an international consensus statement. Br J Sports Med 2016; 50: 1169-76.

4. 4.Parvizi J, Leunig M, \& Ganz R. Femoroacetabular impingement. JAAOS-J Am Academy Orthopaedic Surg 2007; 15: 561-70.

5. Dudda M, Albers C, Mamisch TC, Werlen S, Beck M. Do normal radiographs exclude asphericity of the femoral headneck junction? Clin Orthop Relat Res 2009; 467: 651-9.

6. Barton C, Salineros MJ, Rakhra KS, Beaulé PE. Validity of the alpha angle measurement on plain radiographs in the evaluation of cam-type femoroacetabular impingement. Clin Orthopaedics Related Res 2011; 469: 464-9.

7. Ersan Ö, Yıldıı Y, Ateş Y. Femoroasetabuler sııışma. Totbid Derg 2010; 9: 107-14.

8. Tanzer M, Noiseux N. Osseous abnormalities and early osteoarthritis: the role of hip impingement. Clin Orthopaedics Related Res 2004; 429: 170-7.

9. Tannast M, Siebenrock KA, Anderson SE. Femoroacetabular impingement: radiographic diagnosis-what the radiologist should know. Am J Roentgenol 2007; 188: 1540-52.

10.Laborie LB, Lehmann TG, Engesæter IØ, Eastwood DM, Engesæter LB, Rosendahl K. Prevalence of radiographic findings thought to be associated with femoroacetabular impingement in a population-based cohort of 2081 healthy young adults. Radiology 2011; 260: 494-502.

11. Azboy I, Ceylan HH, Groff H, Vahedi H, Parvizi J. Bilateral femoroacetabular impingement: What is the fate of the asymptomatic hip?. Clin Orthopaedics Related Res 2019; 477: 983-9. 
12. Allen D, Beaulé PE, Ramadan O, Doucette S. Prevalence of associated deformities and hip pain in patients with cam-type femoroacetabular impingement. The Journal of bone and joint surgery. British Vol 2009; 91: 589-94.

13.Şahin N, Atıcı T, Öztürk A, Özkaya G, Avcu B, Özkan Y. Kronik kalça ağrısı ile femoroasetabuler sıkışma arasındaki ilişki: Klinik bulgular ve radyografi ile değerlendirme. Eklem Hast Cerr 2011; 22: 129-33.

14. Hatakeyama A, Utsunomiya H, Nishikino S, et al. Predictors of poor clinical outcome after arthroscopic labral preservation, capsular plication, and cam osteoplasty in the setting of borderline hip dysplasia. Am J Sports Med 2018; 46: 135-43.

15. Chen L, Boonthathip M, Cardoso F, Clopton P, Resnick D. Acetabulum protrusio and center edge angle: new MR-imaging measurement criteria-a correlative study with measurement derived from conventional radiography. Skeletal Radiol 2009; 38: 123-9.

16. Monazzam S, Bomar JD, Cidambi K, Kruk P, Hosalkar H. Lateral center-edge angle on conventional radiography and computed tomography. Clin Orthopaedics Related Res 2013; 471: 2233-37.

17. Chadayammuri V, Garabekyan T, Jesse MK, at al. Measurement of lateral acetabular coverage: a comparison between CT and plain radiography. J Hip Preservation Surg 2015; 2: 392-400.

18.Ji HM, Baek JH, Kim KW, Yoon JW, Ha YC. Herniation pits as a radiographic indicator of pincer-type femoroacetabular impingement in symptomatic patients. Knee Surg Sports Traumatol Arthroscopy 2014; 22: 860-6 